\title{
Ham ve Sentetik Atıksularda Su Mercimeği (Lemna minor L.) Kullanılarak Karbon ve Besi Maddelerinin Gideriminin İncelenmesi ve Karşılaştırılması
}

\author{
The Investigation and Comparison of Carbon and Nutrient Removal from Domestic and \\ Synthetic Wastewaters Using Duckweed (Lemna Minor L.)
}

\author{
Orhan GÖKYAY ${ }^{1}$ (ORCID ID: 0000-0001-8262-6645), Melih BALCIGIL ${ }^{2}$ \\ ${ }^{1}$ Marmara Üniversitesi, Çevre Mühendisliği Bölümü, 34722, Kadıköy/İstanbul, TÜRKIYE. \\ ${ }^{2}$ Marmara Üniversitesi, Fen Bilimleri Enstitüsü, Çevre Mühendisliği Bölümü, 34722, Kadıköy/İstanbul, TÜRKIYE
}

Öz

Bu çalışmanın amacı, su mercimeği (Lemna minor L.) bitkisinin atık sulardan besi maddesi ve karbon giderim kapasitesinin araştırılması ve atık su arıtımındaki kullanım alanlarının belirlenmesidir. Çalışmanın başlangıcında, Ege Üniversitesi'nden temin edilen Lemna minor bitkisinin doğal koşulların ardından kontrollü koşullar altında adaptasyonuna çalışılmıştır. Çalışma, Marmara Üniversitesi Biyoloji ve Çevre Mühendisliği Bölümleri Laboratuvarlarında gerçekleştirilmiştir. Laboratuvar koşullarında çoğaltılan su mercimeklerinin Kimyasal Oksijen İhtiyacı (KOİ), $\mathrm{NH}_{3}-\mathrm{N}, \mathrm{NO}_{3}-\mathrm{N}$ ve $\mathrm{PO}_{4}$-P giderim verimliliği sentetik ve gerçek atık sular kullanılarak araştırılmıştır. Deneysel çalışmalar 3000 ml'lik plastik kaplarda gerçekleştirilmiş ve havuz sistemi esas alınmıştır. Evsel ve sentetik atıksular ile gerçekleştirilen çalışmalarda,

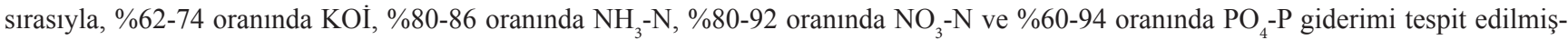
tir. Su mercimekleri nihai arıtma seviyelerine yaklaşık bir hafta sonunda ulaşmaktadır. Su mercimeğine dayalı arıtma sistemlerinin, atık su arıtma tesislerinde yer alan son çöktürme havuzlarında, kolaylıkla yetişebilmesi açısından özellikle kırsal kesimlerde nüfusun az olduğu yerlerde uygulanabileceği sonucuna varılmıştır.

Anahtar Kelimeler: Su mercimeği (Lemna minor), besi maddesi giderimi, KOİ giderimi, atıksu arıtma, bitkisel arıtma

\begin{abstract}
This study aims to investigate the nutrient and carbon removal capacity from wastewaters and determine the role of Lemna minor L. to treat wastewaters. At the beginning of the study, adaptation of duckweeds to lab conditions were focused which were provided from Ege University. Experiments were conducted in Marmara University Biology and Environmental Engineering Departments. Chemical Oxygen Demand (COD), $\mathrm{NH}_{3}-\mathrm{N}, \mathrm{NO}_{3}-\mathrm{N}$ and $\mathrm{PO}_{4}-\mathrm{P}$ removal efficiencies of duckweeds were investigated. Experiments were conducted in plastic containers with $3000 \mathrm{ml}$ of active reactor volume, using pond system principles. The experiments were conducted with synthetic and domestic wastewaters. Duckweed was efficient in removal of nutrients (62-74\% COD, 80-86\% $\left.\mathrm{NH}_{3}-\mathrm{N}, 80-92 \% \mathrm{NO}_{3}-\mathrm{N}, 60-94 \% \mathrm{PO}_{4}-\mathrm{P}\right)$. Duckweed was able to reach ultimate removal efficiency in one week. Therefore, since they grow easily, duckweed based treatment systems can be implemented for small-scale treatment facilities which serve locations with low population, after secondary clarifiers in advanced biological treatment systems.
\end{abstract}

Keywords: Duckweed, nutrient removal, COD removal, wastewater treatment, phytoremediation.

\section{GİRIŞ}

Günümüzde yüzen su bitkileriyle arıtım tekniği tüm dünyada uygulanmaktadır. Su mercimeği bu amaçla kullanılan bitkilerden biridir ve oluşturulan sistemlerde atık su arıtımı için temel ilke, hem bitkilerin hem de mikroorganizmaların birlikte büyümesidir. Su mercimeği, atık suların arıtılmasında aerobik ve anaerobik bakteriler ile işbirliği içindedir [1]. Bitkisel arıtma sistemlerinde kullanılan su mercimekleri 
ülkemizde kolay bulunabilmesi, ekonomik olması ve rahatlıkla yetişebilmesi açısından özellikle nüfusun az olduğu kırsal kesimlerde yararlanılması uygundur [2].

Fiziksel, kimyasal ve biyolojik arıtmalar en çok kullanılan atık su arıtma yöntemleri olmakla beraber bahsi geçen arıtma yöntemlerinin ilk yatırım ve enerji maliyetleri yüksek, işletim ve bakımları ise oldukça güçtür. Bu nedenle alternatif bir arıtma yöntemi olan bitkisel arıtım, son zamanlarda atık sulardan organik karbonun yanında besi maddelerinin giderilmesinde de kullanılmaktadır [3]. Bitkisel arıtma diğer arıtma yöntemleri (fiziksel, kimyasal, biyolojik) ile karşılaştırıldığında fazla insan gücü gerektirmeyen, işletilmesi kolay ve asgari enerji gereksinimi olan alternatif bir arıtma yöntemidir. Bitkisel arıtım, ötrofikasyonun olumsuz etkilerini azaltır, su kaynaklarından azot ve fosfor giderilmesini amaçlar. Bitkiler, kirlenmiş suların kalitesinin iyileştirilmesinde farklı etkilere sahip olmakla birlikte ağır metalleri kendi bünyelerinde biriktirme ve azot, fosfor gibi organik kirleticileri kendi biyolojik faaliyetleri haricinde yüksek miktarda organizma içerisinde tutulmasını da sağlamaktadırlar. Su bitkileriyle arıtma işleminde çökelme, adsorpsiyon, bakteriyel ayrışma ve bitkisel kullanım gibi arıtma mekanizmaları etkindir [4]. Su mercimekleri (Lemna minor L.) ve sucul eğreltilerden Azolla bitkisel arıtım uygulamalarında başarılı bir şekilde kullanılabilir [5]. Su mercimekleri biyolojik arıtma sistemlerinde üçüncül bir arıtma sağlamak ve daha iyi bir çıkış suyu elde etmek amacıyla da kullanabilmektedir. Su mercimeklerine dayalı bazı tam ölçekli sistemler ABD, Çin, Belçika, Tayvan ve Bangladeş’te işletilmektedir.

Bitkisel arıtım teknolojisi temel süreç ve uygulanabilirliği temelinde fitoekstraksiyon, rizofiltrasyon, fitostabilizasyon, fitovolatilizasyon ve fitodegredasyon olmak üzere 5 farklı gruba ayrılmaktadır. Atıksulardan Lemna minor ile gerçekleştirilen besi maddesi ve karbon gideriminde rizofiltrasyon mekanizması etkin rol oynamakta olup, bitki kökleri tarafından sıvı büyüme ortamlarından fazla miktardaki besi maddelerinin alımını kapsamaktadır [6].

Su mercimekleri; Lemnaceae familyasına dâhil olan, çok küçük, yüzebilen, yaprakları birkaç mm genişliğinde olan, sucul makrofitlerdir [2]. Su mercimekleri, 5-9 pH aralığında yaşamakla birlikte $6,5-7,5 \mathrm{pH}$ aralığında ve $20-30$ ${ }^{0} \mathrm{C}$ sicaklıkta iyi gelişim gösterir [4]. Besi maddesi bakımından zengin sularda yetiştiğinde $\% 35-45$ protein bulundurmaları yanında, yapılarında \%10-15 oranında lif içerirler. Su mercimeği, hızlı büyüme oranıyla, yüksek seviyede besi maddesi giderimi, düşük lif ve yüksek protein içeriğinden dolayı tercih edilmektedir. Ayrıca su mercimekleri kolaylıkla hasat edilebilir ve alg gelişimini önleyebilir. Diğer su bitkilerinden farklı olarak, Lemna minor su kalitesi çalışmalarında ağır metal ve diğer su kirleticilerinin tespit ve gözlemlenmesinde de kullanılabilmektedir [7].

Çalışmada ilk olarak doğal ortamından getirilen su mercimeklerinin kontrollü şartlar altındaki laboratuvar koşullarına adaptasyonu ve kültürü amaçlanmıştır. Ardından ideal su mercimeği yoğunluğu ile laboratuvar koşullarında hazırlanan sentetik atık sulardan Kimyasal Oksijen İhtiyacı (KOI) ve besi maddesi giderimi $\left(\mathrm{NH}_{3}-\mathrm{N}, \mathrm{NO}_{3}-\mathrm{N}, \mathrm{PO}_{4}-\mathrm{P}\right)$ araştırılmıştır. Besi maddesi gideriminde sentetik atıksular denendikten sonra Paşaköy İleri Biyolojik Atık Su Arıtma Tesisi'nden (PİBAAT) temin edilen atıksu sisteme verilerek KOİ ve besi maddesi giderim oranları incelenmiş ve karşılaştırılmıştır.

\section{MATERYAL VE YÖNTEM}

Deneysel çalışmalarda kullanılan Lemna minor bitkisi Ege Üniversitesi Botanik Bahçesi'nden tedarik edilmiştir. Marmara Üniversitesi Çevre Mühendisliği Laboratuvarı'na getirilen su mercimeklerine iki dakika süre ile $\% 0,5$ 'lik sodyum hipoklorit ile dezenfeksiyon işlemi uygulanmıştır [7]. Sentetik su ve atık su ve içeren suların arıtılabilirlik çalışması için Marmara Üniversitesi Fen Edebiyat Fakültesi Biyoloji Bölümü'ne ait olan Bitki Yetiştirme Odası ve Laboratuvarı kullanılmıştır. Bitki yetiştirme odasının sıcaklığı ve nemi, su mercimeğinin en uygun büyüme koşullarına yakın olan $22^{0} \mathrm{C}$ ve $\% 60-70$ oranında sabit tutulmuştur. Yetiştime odas 1 dış ortamdan 1şık almayı engelleyecek şekilde olup, bitkiler için gerekli olan 1şık Osram Fluora L 36 W/77 model 1400 lümen 1şık yayan lambalarla elde edilmiştir. Lambalar zamanlayıcıya bağlanıp, gün ışığına benzetilmek üzere 16 saat aydınlığı takiben 8 saat karanlık periyot yaratılmıştır [8]. Su mercimeği kültüründe ve atıksu arıtmada $40 \times 20 \times 13 \mathrm{~cm}$ ölçülerinde dikdörtgen ve $30 \mathrm{~cm}$ çapında dairesel plastik küvetler kullanılarak havuz sistemi uygulanmıştır.

Laboratuvar ortamında farklı içeriklerde hazırlanan sentetik atık su (Huttner solüsyonu) [9] ve Paşaköy İleri Biyolojik Atık Su Arıtma Tesisi'nden elde edilen evsel atık suların Lemna minor L. ile arttılabilirliğinin tespit edilmesi amacıyla besi maddesi ve karbon giderim çalışmaları gerçekleştirilmiştir. Huttner solüsyonunun içeriği Tablo 1'de verilmiştir. Yapılan çalışmalarda, Bitki Yetiştirme Odası'nda bulunan küvetlere 3 litre hacminde sentetik ve evsel atıksu doldurulmuştur. Küvetlere atıksular aktarıldıktan sonra 0,75 $\mathrm{kg} / \mathrm{m}^{2}$ esasına göre su yüzeyini $\% 50, \% 75$ ve $\% 100$ oranlarında kaplayacak şekilde su mercimekleri yerleştirilmiş ve 7 günlük bekleme süresi esas alınarak analizler gerçekleştirilmiştir [10]. Arıtılabilirlik için yapılan çalışmalar üçer defa tekrarlanmış ve ortalamaları verilmiştir. Atıksular deney sonunda değiştirilmiştir. 
Yapılan çalışma esnasında sıcaklığın yanı sıra Kimyasal Oksijen İhtiyac1 (KOİ), $\mathrm{NO}_{3}-\mathrm{N}, \mathrm{NH}_{3}-\mathrm{N}$ (Nessler Yöntemi), $\mathrm{PO}_{4}-\mathrm{P}$ ölçümleri standart metotlara göre ölçülmüştür [11]. Besi maddesi ve karbon giderimi çalışmalarında sentetik atık su olarak kullanılan Huttner solüsyonu Tablo 1'de belirtilen içerikte hazırlanmış olup, bu içeriğe 2,9 g/L sükroz $\left(\mathrm{C}_{12} \mathrm{H}_{22} \mathrm{O}_{11}\right), 2,6 \mathrm{~g} / \mathrm{L}$ sodyum asetat $\left(\mathrm{CH}_{3} \mathrm{COONa}\right)$ ve $0,7 \mathrm{mg} / \mathrm{L}$ propiyonik asit $\left(\mathrm{CH}_{3} \mathrm{CH}_{2} \mathrm{COOH}\right)$ ilave edilmiştir. Besi maddesi ve karbonun giderimi çalışmalarında kullanılan Paşaköy İleri Biyolojik Atık Su Arıtma Tesisi giriş suyu parametreleri Tablo 2'de belirtilmiştir.

Tablo 1. Sentetik atıksu (Huttner solüsyonu) içeriği [9]

\begin{tabular}{ll}
\hline Besi Maddesi & Konsantrasyon $(\mathrm{mg} / \mathrm{L})$ \\
\hline $\mathrm{CaCl}_{2}$ & 12,2 \\
$\mathrm{EDTA}$ & 50,0 \\
$\mathrm{~K}_{2} \mathrm{HPO}_{4}$ & 40,0 \\
$\mathrm{NH}_{4} \mathrm{NO}_{3}$ & 20,0 \\
$\mathrm{ZnSO}_{4} 7 \mathrm{H}_{2} 0$ & 6,5 \\
$\mathrm{H}_{3} \mathrm{BO}_{3}$ & 1,5 \\
$\mathrm{Na}_{2} \mathrm{MoO}_{4} \cdot \mathrm{H}_{2} \mathrm{O}$ & 2,5 \\
$\mathrm{CuSO}_{4} \cdot 5 \mathrm{H}_{2} \mathrm{O}$ & 0,4 \\
$\mathrm{CoSO}_{4} \cdot 7 \mathrm{H}_{2} 0$ & 0,02 \\
$\mathrm{MnCl}_{2} \cdot 4 \mathrm{H}_{2} \mathrm{O}$ & 3,5 \\
$\mathrm{FeSO}_{4} \cdot 7 \mathrm{H}_{2} 0$ & 2,5 \\
$\mathrm{MgSO}_{4} \cdot 7 \mathrm{H}_{2} 0$ & 50,0 \\
\hline
\end{tabular}

Tablo 2. Paşaköy İleri Biyolojik Atıksu Arıtma Tesisi girişi suyu parametreleri [12]

\begin{tabular}{lc}
\hline Parametre & Konsantrasyon $(\mathrm{mg} / \mathrm{L})$ \\
\hline Askıda Katı Madde & 500,0 \\
Biyolojik Oksijen İhtiyacı & 325,0 \\
Kimyasal Oksijen İhtiyac1 & 600,0 \\
Toplam Kjeldahl Azotu & 70,0 \\
Toplam Fosfor & 8,0 \\
\hline
\end{tabular}

\section{III: BULGULAR VE TARTIŞMA}

\subsection{KOİ Giderimi}

Çalışmanın başlangıç aşamasında ideal su mercimeği yoğunluğunu bulmak amaçlanmıştır. Arıtım çalışmalarında kullanılan küvetlerin yüzey alanları en az $0,75 \mathrm{~kg} / \mathrm{m}^{2}$ esasina göre $\% 50, \% 75$ ve $\% 100$ olacak şekilde su mercimeği ile doldurulmuştur ve karar verebilmek için KOİ giderimlerine bakılmıştır. Yüzey alanı \%50 ve \%75 Lemna minor ile kaplanmış şekilde yapılan KOİ giderim araştırmalarında önemli bir giderim farkı bulunmamıştır. Bu nedenle \%50 ve \%100'lük yüzey alanı kaplayacak şekilde iki farklı çalışma karşılaştırılmış, Şekil 1'de görüldüŭüü üzere \%5'lik giderim farkı olması ve deney süresince mevcut bulunan su mercimeği miktarının etkin kullanılabilmesi hedeflenerek sonraki çalışmalar, yüzey alanda $\% 50$ su mercimeği olacak şekilde sürdürülmüştür.

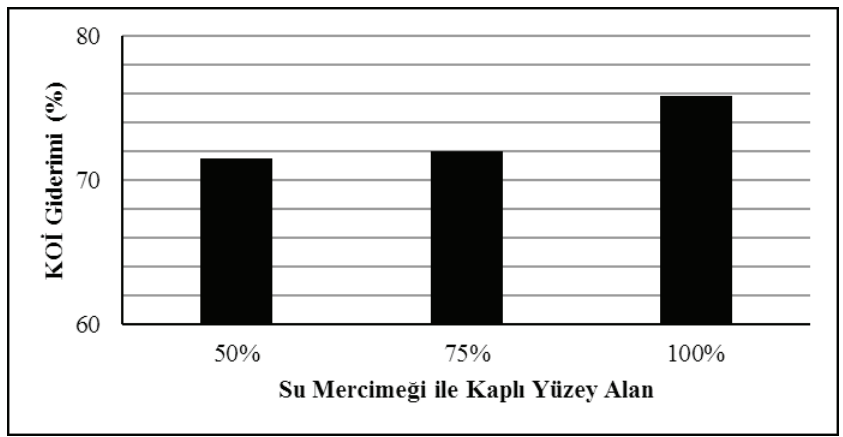

Şekil 1. Farklı su mercimeği yüzey alanına sahip çalışmaların KOİ giderimi bakımından karşılaştırılması

$\mathrm{Su}$ mercimeklerinin KOİ giderim kapasitesini belirleyebilmek amacıyla hazırlanan sentetik atık su değişik seyreltme oranlarıyla küvetlere beslenmiştir. Elde edilen sonuçlara göre Lemna minor düşük ve orta KOİ $(<500$ $\mathrm{mg} / \mathrm{L}$ ) konsantrasyonlarını gidermede oldukça başarılı görülmüş, yüksek konsantrasyonlu KOİ içeren atık sularda yeterli arıtımı sağlayamamıştır. Farklı konsantrasyonlarda KOİ içeren sentetik atık sulardan su mercimekleri ile elde edilen KOİ giderimleri Şekil 2'de verilmiştir. Leng (1999) yaptığı çalışmada, $461 \mathrm{mg} / \mathrm{L}$ 'lik KOİ giriş konsantrasyonuna sahip atıksuda \%30'luk giderim olduğunu gözlemlemiş̧ir [13]. Bu yapılan çalışmada hesaplanan KOİ giderim oranı düşük derecede KOİ içeren sularda $\% 74$, orta derecede KOİ içeren sularda \%54 olarak bulunmuştur.

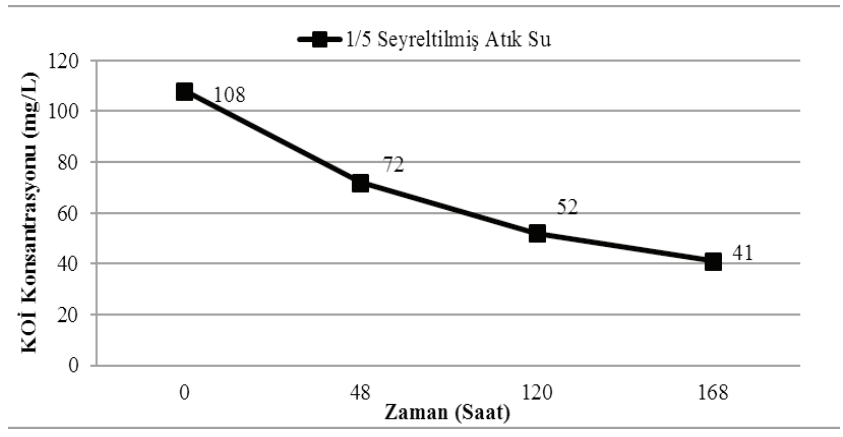

Şekil 2. Farklı KOİ konsantrasyonlarına sahip sentetik atıksulardan karbon giderimi

Daha önceden Tablo 2'de verildiği gibi Paşaköy İleri Biyolojik Atık Su Arıtma Tesisi'nden getirilen atık suyun KOİ değerleri yüksektir. Sentetik atıksu ile yapılan testlerde, KOİ 
değeri yüksek olduğunda, su mercimeklerinin giderimde başarılı olamadığı göz önünde bulundurularak atıksu $1 / 5$ oranında seyreltilerek sisteme beslenmiştir. Su mercimeklerinin ham atıksu ortamında KOİ giderimleri incelenmiş ve sonuçlar Şekil 3’te verilmiştir.

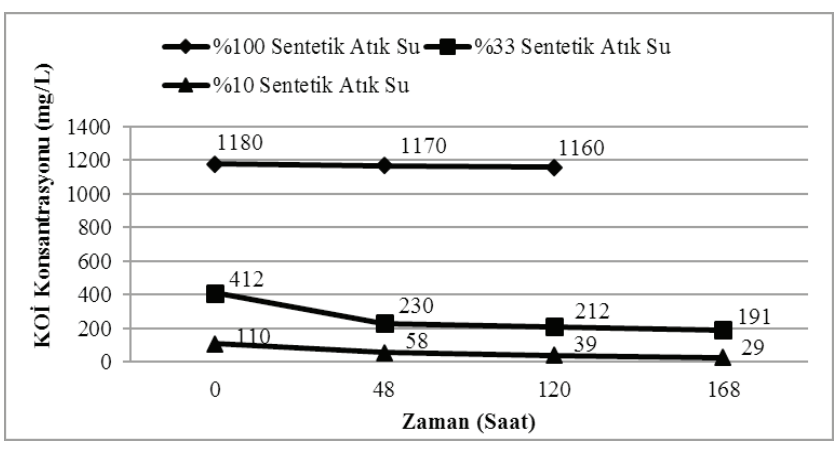

Şekil 3. 1/5 seyreltilmiş evsel atıksudan KOİ giderimi

Düşük konsantrasyonlu sentetik atık suda $\% 74$ olarak hesaplanan KOİ giderim oranının Paşaköy İleri Biyolojik Atık Su Arıtma Tesisi'nden getirilen ham suda yapılan deneyler sonucunda \%62'ye düştüğü görülmüştür (Ham atıksu ve sentetik atıksu ile yapılan deneylerde ortaya çıkan farklılıkların sebebi ileride tartışılacaktır). El-Shafai ve $a r k$. (2007) yaptığı çalışmada UASB tankının çıkış suyunun KOİ konsantrasyonunun yaz aylarında ortalama $151 \mathrm{mg} / \mathrm{L}$, kış aylarında ise ortalama $257 \mathrm{mg} / \mathrm{L}$ olduğunu ve bu konsantrasyonlara karşılık gelen KOİ arıtımının yaz aylarında \%64, kış aylarında \%72 olarak ölçüldüğünü belirtmişlerdir [14]. Körner ve ark. (1999) su mercimeği ile kontrol edilen sistemlerde KOİ konsantrasyonun ortalama olarak $300 \mathrm{mg} / \mathrm{L}$ olduğu evsel atıksuda üç gün içinde \%74-78 aralığında giderim olduğunu keşfetmiştir [15]. Ran ve ark. (2004) ortalama KOİ değeri 298,2 mg/L olan evsel atıksu ile pilot öl-

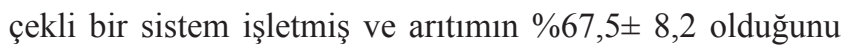
ifade etmiştir [16]. Shah ve ark. (2015) su mercimeği ile doldurulmuş bir havuzda evsel atıksu kullanmış ve KOİ giderimini \%26,4 olarak belirlemiştir [17]. İstanbul Su ve Atıksu İdaresi (İSKİ) yönetmeliğine göre bir atıksu arıtma tesisinin çıkış değeri KOİ için $180 \mathrm{mg} / \mathrm{L}$ 'den az olmak zorundadır. Günümüzde İstanbul'da işletilmekte olan iki atıksu arıtma tesisinin ortalama KOİ çıkış değerleri 136 ve 125 mg/L'dir. Bahsi geçen bu ortalama tesis çıkış değerleri Şekil 3'te belirtilen KOİ değerlerine çok yakındır ve bu değerler için su mercimeği, literatür verileri ile karşılaştırıldığında, çok iyi bir giderim sağlamıştır. Buna göre, su mercimeği atıksu arıtma tesis çıkış suyunda kullanılabilir ve iyi bir son arıtma olabilme özelliğine sahiptir.

\subsection{Besi Giderimi}

$\mathrm{Bu}$ çalışmada su mercimeğinin $\mathrm{NH}_{3}-\mathrm{N}, \mathrm{PO}_{4}-\mathrm{P}$ ve $\mathrm{NO}_{3}-\mathrm{N}$ giderimleri hem sentetik atıksu hem de atıksu arıtma tesisinden getirilen ham atıksu üzerinde incelenmiştir ve Lemna minor L.'un besi gideriminde başarılı olduğu görülmüştür.

Şekil 4'te değişik $\mathrm{NH}_{3}-\mathrm{N}$ konsantrasyonu bulunan sentetik atık su ile beslenen Lemna minor giderimleri görülmektedir. Düşük, orta ve yüksek $\mathrm{NH}_{3}-\mathrm{N}$ konsantrasyonlarında oldukça yüksek giderim yüzdeleri sağlanmıştır. Elde edilen giderimler sırasıyla $\% 90, \% 86$ ve $\% 86$ olarak hesaplanmıştır. Bu sonuç Tarlan ve ark. (2005) ile benzerlik göstermektedir [1].

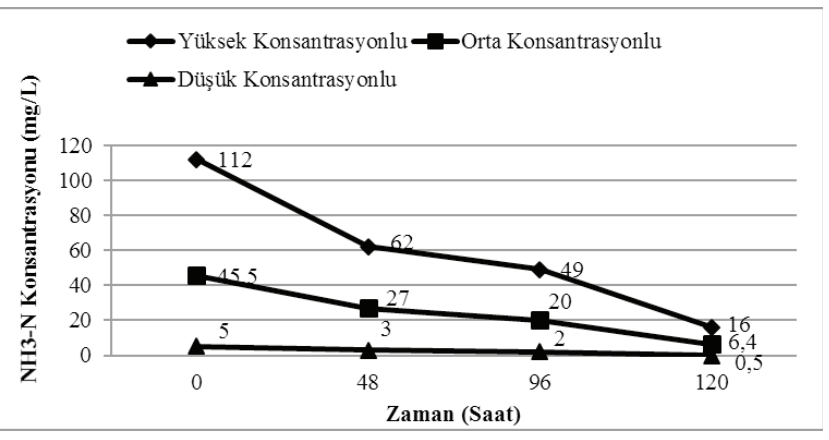

Şekil 4. Düşük, orta ve yüksek seviyede $\mathrm{NH}_{3}-\mathrm{N}$ içeren sentetik atık sulardan $\mathrm{NH}_{3}-\mathrm{N}$ giderimi

El-Shafai ve ark. (2007) 18,8 mg/L giriş değerine sahip amonyak kullandığında, su mercimeği havuzunda yaz aylarında \%98 giderim verimliliği sağladığını fakat kış aylarında bu değerin keskin bir biçimde \%44'e düştüğü sonucuna varmıştır [14]. Mohedano ve ark. (2012) domuz atığı ile beslenen seri su mercimeği havuzlarından oluşan bir sistemde $\mathrm{NH}_{3}-\mathrm{N}$ giderimini \%98,8 olarak ölçmüştür [18]. Bu çalışmada en yüksek amonyak giderimin ilk iki günde olduğu, bu oranın \%40-45 civarında gerçekleştiği tarafımızdan gözlemlenmiştir. Bu esnada ölçülen $\mathrm{pH}$ değerinin ise dörtten altıya çıkmıştır. Bu değerler Ran ve ark. (2004) tarafindan yürütülen deneylerden elde edilen sonuçlarla uyum göstermiştir [16].

Sentetik atıksu ile yapılan deneylerden sonra $\mathrm{NH}_{3}-\mathrm{N}$ giderimini görmek için su mercimekleri PIBBAAT’nden elde edilen ham atıksu ile beslenmiş, fakat düşük bir verim (yaklaşı \%25) elde edilmiştir. Bundan sonra ham atıksu 1/5 oranında seyreltilerek sisteme beslenmiş ve Şekil 5'te görülen grafik elde edilmiştir. Buna göre benzer konsantrasyonda sentetik atıksu kullanılarak elde edilen verilen \%86 olarak gerçekleşen arıtma verimi, ham atıksuda bir miktar düşerek $\% 80$ olarak hesaplanmıştır. Bu düşüşteki farklılı̆ı̆ı sebebi ham atıksuda bulunan çeşitli mikroorganizmalar, ağır metaller veya diğer eser miktardaki maddelerin olabileceği düşünülmektedir. Shah ve ark. (2015) evsel atıksu kullanarak yaptıkları deneylerde \%17,59 
$\mathrm{NH}_{3}-\mathrm{N}$ giderimi bulmuştur [17]. Mohapatra ve ark. (2012) ise havuz sistemi ile kullandıkları düşük $\mathrm{NH}_{3}-\mathrm{N}$ konsantrasyonlu atıksuda maksimum \%61,87 arıtım sağlamışlardır [19].

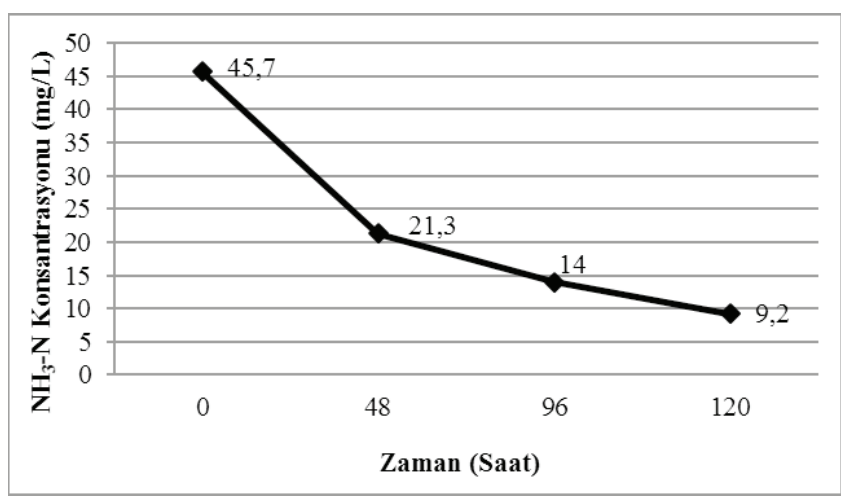

Şekil 5. Seyreltilmiş (1/5 oranında) ham atıksudan $\mathrm{NH}_{3}-\mathrm{N}$ giderimi

Su mercimekleri kullanılarak ham atıksu ve sentetik atıksuda fosfat fosfor giderimleri de araştırılırmıştır ve sonuçlar Şekil 6'da verilmiştir. Buna göre yüksek $\mathrm{PO}_{4}-\mathrm{P}$ konsantrasyonu içeren sentetik sularda giderim \%87-94 aralığında gerçekleşmiş, daha düşük konsantrasyonu olan sentetik atıksu da ise bu oran $\% 82$ olarak hesaplanmıştır. 168 saat süren deneylerde ortalama $\mathrm{PO}_{4}-\mathrm{P}$ giderim hızı tüm konsantrasyonlar göz önüne alındığında 2,6 mg/L/gün olarak bulunmuştur. Yüksek ve düşük konsantrasyonlar olarak ayırdığımızda ise, bu hızlar 3,2 ve 1,4 mg/L/gün olarak ölçülmüştür. Giderim oranları ve hızlardan da açıkça anlaşılabileceği gibi daha yüksek $\mathrm{PO}_{4}-\mathrm{P}$ konsantrasyonu olan sentetik atıksularda giderim de fazla ve hızlı olmuştur. Elde edilen giderimlerin büyük bir oranı (ortalama \%60) ilk iki günde gerçekleşmiş ve sonraki zamanda bu oran azalmıştır.

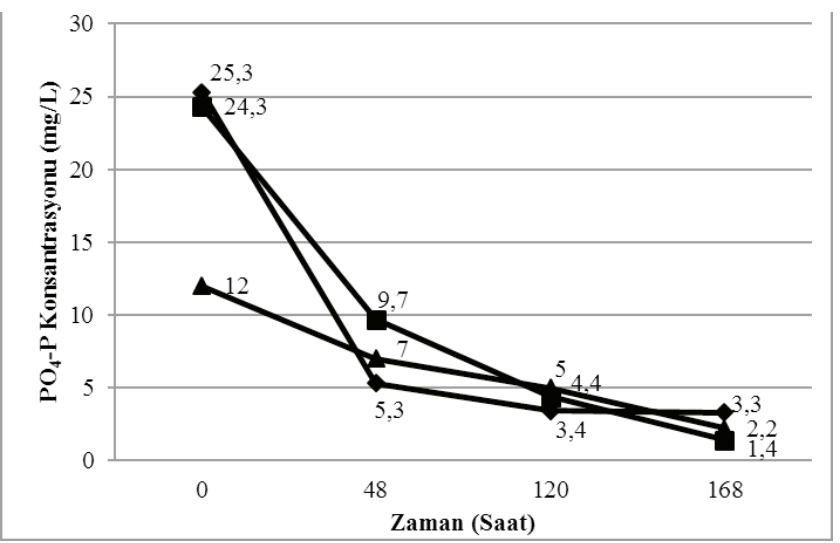

Şekil 6. Farklı konsantrasyonlu sentetik atık sulardan $\mathrm{PO}_{4}-\mathrm{P}$ giderimi
PIBBAAT'nden getirilen atıksularda yapılan $\mathrm{PO}_{4}-\mathrm{P}$ ar1tım deneylerden elde edilen sonuçlar Şekil 7'de verilmiştir. Daha önceki deneylerde de görüldüğü gibi gerçek atıksu kullanılan sonuçlar sentetik atıksudan elde edilen sonuçlarda farklıdır. Buna göre benzer konsantrasyondaki $\mathrm{PO}_{4}-\mathrm{P}$ giderimleri sentetik atıksularda \%87-94 aralığında gerçekleşirken, ham atıksuda bu oran \%60 civarına kadar düştüğü gözlemlenmiştir. Benzer biçimde, arıtım hızı 2,57 mg/L/gün olarak hesaplanmıştır. Bu hız, sentetik atıksularda ölçülenden daha düşüktür. $\mathrm{PO}_{4}-\mathrm{P}$ giderimi için yapılan benzer çalışmalara bakıldığında, Tarlan ve ark. (2005) ham atıksuda $\% 82$ arıtım bulmuşlardır [1]. Jena ve ark. (2010) çöktürme tankı çıkış suyu ile besledikleri havuz sistemli çalışmada $\mathrm{PO}_{4}$-P giderimini \%71 olarak ölçmüşlerdir [20]. Gürtekin ve Şekerdağ (2008) ise yine çöktürme tankı çıkış suyu kullandıkları çalışmalarında $\mathrm{PO}_{4}-\mathrm{P}$ arıtımını $\% 45$ seviyesinde bulmuşlardır [21]. Bu çalışmada elde edilen değerlerin literatürde yer alan verilerin aralığında olduğu görülmüsstür.

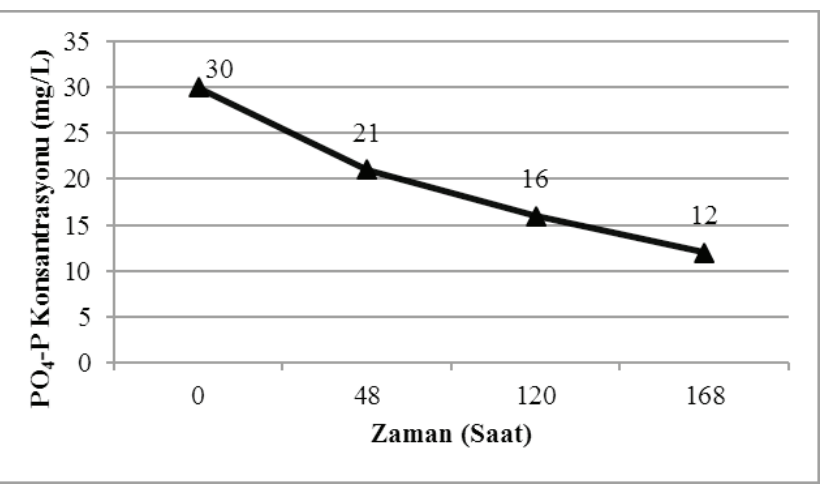

Şekil 7. Ham atıksulardan $\mathrm{PO}_{4}-\mathrm{P}$ giderimi

$\mathrm{Bu}$ çalışma esnasında su mercimeklerinin $\mathrm{NO}_{3}-\mathrm{N}$ arıtımı konusundaki performansına da bakılmıştır. Sentetik atıksu kullanılarak yapılan analizlerde $\mathrm{NO}_{3}-\mathrm{N}$ başlangıç konsantrasyonunun ortalama olarak $24 \mathrm{mg} / \mathrm{L}$ olduğu belirlenmiştir. Buna göre 7-gün testlerinde arıtım oranı $\% 92$, giderim hızı $3,15 \mathrm{mg} / \mathrm{L} /$ gün olarak hesaplanmıştır. Bu verilere ek olarak, giderimin \%80'i ilk iki günde gerçekleşmiştir. PİBAAT'nden elde edilen $15 \mathrm{mg} / \mathrm{L}$ başlangıç konsantrasyonuna sahip ham atıksu kullanılarak yapılan analizlerde ise giderim oranının $\% 81$ 'e, giderim hızının ise $3,15^{\prime}$ ten $1,7 \mathrm{mg} / \mathrm{L} /$ gün'e düştüğü gözlenmiştir. Giderim hızları karşılaştırıldığında, sentetik atıksu kullanılarak yapılan deneylerdeki hız, ham atıksudakilere göre yaklaşık olarak \%50 daha hızlı olduğu ortaya çıkmaktadır. Tarlan ve ark. (2005) 0,3 mg/L $\mathrm{NO}_{3}-\mathrm{N}$ içeren giriş suyunda $\% 90$ giderim sağlamıştır [1]. Özengin ve Elmacı (2007) yaptıkları çalışmada ideal koşullar altında atıksuda bulunan toplam azotu \%83-87 oranında 
giderebildiklerini belirtmişlerdir [22]. Sims ve ark. (2013) yağmur suyu arıtma havuzunda bulunan nitratı $\% 56$ oranında arıtabildiklerini ölçmüşlerdir [23]. Hem sentetik hem de ham atıksu ile yapılan deneylerde literatürde bulunan verilerin benzerlerinin elde edildiği görülmüştür. Ayrıca besi gideriminin önemli bir kısmı ilk iki günde sağlanmış fakat asıl sonuç yedi gün sonra ortaya çıkmıştır.

Ham atıksu ve sentetik atıksu ile yapılan deneyler sonucunda, su mercimeklerinin orta ve düşük konsantrasyona sahip atıksularda hem karbon hem de besi maddelerinin giderimi konusunda başarılı olduğu düşünülmektedir fakat atıksu arıtma tesislerine gelen yüksek kirletici konsantrasyonuna sahip atıksular yerine daha çok arıtım sonrası çıkış sularında kullanılmasının daha doğru olduğu sonucuna varmak mümkündür. Aşağıdaki Tablo 3'te verilen son çöktürme tankı çıkış suyu karakterine sahip sularda, su mercimeklerinden arıtma sonrası "parlatma" aşaması olarak yararlanmanın daha uygun olacağını ifade etmek gerekmektedir.

Tablo 3. Son çöktürme havuzlarındaki atık su karakterizasyonu [21]

\begin{tabular}{lc}
\hline Parametre & Konsantrasyon $(\mathrm{mg} / \mathrm{L})$ \\
\hline COD, $\mathrm{mg} / \mathrm{L}$ & $260 \pm 11$ \\
Ammonium $\left(\mathrm{NH}_{3}-\mathrm{N}\right), \mathrm{mg} / \mathrm{L}$ & $175 \pm 3$ \\
Nitrate $\left(\mathrm{NO}_{3}-\mathrm{N}\right), \mathrm{mg} / \mathrm{L}$ & $0,2 \pm 0,2$ \\
Phosphate $\left(\mathrm{PO}_{4}-\mathrm{P}\right), \mathrm{mg} / \mathrm{L}$ & $9 \pm 0,3$ \\
\hline
\end{tabular}

Yapılan ölçümlere ek olarak gerçekleştirilen çalışmalar esnasında su mercimeklerinin köklerinin aşırı olarak uzadığ ve yoğun stok yapılan küvetlerde köklerin birbirine dolandığı gözlemlenmiştir. Sentetik ve ham atık sulardan besi maddesi ve karbon gideriminde kullanılan su mercimeklerinin yapraklarının bir haftalık dönemler sonunda beyazlaştığı ve küçüldüğü, aynı zamanda küvet içerisinde yer alan atık sularda bulanıklığın arttığı tespit edilmiştir. Buradan yola çıkarak, yedi gün sonunda su mercimeklerinin hasat edilmesi gerektiği ortaya çıkmaktadır.

\section{SONUÇ ve DEĞERLENDİRMELER}

Bu çalışmada su mercimeklerinin (Lemna Minor L.) atıksularda karbon ve besi maddelerini gidermede ne kadar başarılı olacağı üzerinde durulmuştur. Çalışma esnasında atıksu olarak laboratuvarda hazırlanan sentetik atıksuyun yanı sıra PİBAAT'nden getirilen ham atıksu da kullanılmış ve sonuçlar elde edilmiştir. Yapılan deneyler sonucunda, havuz yüzeyinin \%50'sinin su mercimeği ile kaplı olmasının yeterli olduğu saptanmıştır. Sentetik atıksu ile yapılan deneylerdeki giderim oranlarının ham atıksuya göre daha yüksek olduğu ve aynı zamanda daha hızlı olduğu ortaya çıkmıştır. Su mercimekleri karbon açısından yüksek konsantrasyonlu ( $>500$ $\mathrm{mg} / \mathrm{L}$ ) atıksuların arıtılmasında başarılı olamamış, orta ve düşük düzeydeki konsantrasyonlarda ise tatmin edici sonuçlar ortaya çıkmıştır. Besi maddesi gideriminde, denemeye tutulan konsantrasyonlar için yüksek oranda giderimler elde edilmiştir. Su mercimeklerinin yapılan yedi günlük testler sonucunda bozulduğu ve bu süre sonunda hasat edilmesi gerektiği gözlenmiştir. Son olarak, su mercimeklerinin son çöktürme tankı çıkış suyu ile beslendiğinde ham atıksu kullanılan durumdan daha iyi bir arıtım gösterebileceği kanısına varılmıştır.

\section{TEŞEKKÜR}

Bu çalışma FEN-C-YLP-130313-0083 numaralı Marmara Üniversitesi BAPKO Lisansüstü Tez projesi kapsamında desteklenmiştir.

\section{KAYNAKLAR}

[1] Tarlan, E., Gür, K. ve Yılmaz, Z. (2005). S.Ü. Kampüs atık sularının karakterizasyonu ve su mercimeği (Lemna minor L.) ile arıtılabilirliği. S.Ü. Müh.-Mim. Fak. Derg., 20, 4-12.

[2] Dalu, J. M. ve Ndamba, J. (2003). Duckweed based wastewater stabilization ponds for wastewater treatment (A low cost technology for small urban areas in Zimbabwe). Physics and Chemistry of the Earth, 28, 1147-1160.

[3] Uysal, Y., Aktas D. ve Caglar Y. (2014). Determination of Color Removal Efficiency of Lemna minor L. from Industrial Effluents. Journal of Environmental Protection and Ecology, 15 (4), 1718-1726.

[4] Topal, M., Karagözoğlu, B., Öbek, E. ve Topal, I. (2011). Bazı su mercimeklerinin nutrient gideriminde kullanımı. MAKUFEBED, 4, 12-28.

[5] Schenker, J. ve Harfmann, D. (2010). Phytoremediation of nutrient controlled water using duckweed and water fern. http://www.skidmore.edu/academics/wri/harfmann_schenker.pdf (Haziran 2012).

[6] Terzi, H. ve Yıldız, M. (2011). Ağır Metaller ve Fitoremediasyon: Fizyolojik ve Moleküler Mekanizmalar. AKÜ-FEBİD, 11, 011001, 1-22.

[7] Khataee, A. R., Movafeghi, A., Torbati, S., SalehiLisar, S. Y. ve Zarei, M. (2012). Phytoremediation potential of duckweed (Lemna minor L.) in degradation of C.I. Acid Blue 92: Artificial neural network modeling. Ecotoxicology and Environmental Safety, 80, 291-298.

[8] Boule, M. K., Vicente, J. A. F., Nabais, C., Prasad, M. N. V. ve Freitas, H. (1999). Ecophysiological tolerans of duckweeds exposed to copper. Aquatic Toxicology, 91, 1-9.

[9] Caicedo, J. R., Van Der Steen, N. P., Arce, O. ve Gijzen, H. J. (2000). Effect of total ammonia nitrogen concentration and 
ph on growth rates of duckweed (Spirodela polyrrhiza). Wat. Res., 34, 15, 3829-3835.

[10] FAO (1998). Duckweed: A tiny aquatic plant with enormous potential for agriculture and environment. http://www.fao. org/ag/againfo/resources/documents/DW/Dw2.htm (Hazi$\operatorname{ran} 2012$ ).

[11] Clesceri, L. S., Greenberg, A. E., Eaton, A. D. ve Franson, M.A.H. (1998). Standard methods for the examination of water and wastewater, 20.bask1.

[12] İstanbul su ve Kanalizasyon İdaresi, http://www.iski.gov.tr/ web/statik.aspx?KID=1000439 (Temmuz 2013).

[13] Leng, R. A. (1999). Duckweed: A tiny aquatic plant with enormous potential for agriculture and environment. University of Tropical Agriculture Foundation.

[14] El-Shafai, S.A., El-Gohary, F.A., Nasr, F.A., Steen N.P. ve Gijzen H.J. (2007). Nutrient Recovery from Domestic Wastewater Using a UASB-Duckweed Ponds System. Bioresource Technology, 98, 798-807.

[15] Körner, S., Lyatuu, G.B. ve Vermaat, J. E. (1998). The influence of Lemna gibba L. on the degradation of organic material in duckweed covered domestic wastewater". Wat. Res., 32, 10, 3092-3098.

[16] Ran, N., Agami M. ve Oron G. (2004). A Pilot Study of Constructed Wetlands Using Duckweed (Lemna gibba L.) for Treatment of Domestic Primary Effluent in Israel. Wat. Res., 38, 2241-2248.
[17] Shah, M., Hashmi, HN., Ghumman, A.R., ve Zeeshan, M. (2015) Performance assessment of aquatic macrophytes for treatment of municipal wastewater. Journal of the South African Institution of Civil Engineering, 57, 3, 18-25.

[18] Mohedano, R.A., Costa, R.H.R., Tavares, F.A., ve Filho, P.B. (2012). High Nutrient Removal Rate from Swine Wastes and Protein Biomass Production by Full-Scale Duckweed Ponds. Bioresource Technology, 112, 98-104.

[19] Mohapatra, D.P., Ghangrekar, M.M., Mitra, A., ve Brar, S.K. (2012). Sewage treatment in integrated system of UASB reactor and duckweed pond and reuse for aquaculture. Environmental Technology, 33, 12, 1445-1453.

[20] Jena, J.K., Patro, B., Patri, P., Khuntia, C.P., Tripathy, N.K., Sinha, S., Sarangi, N., ve Ayyappan, S. (2010) Biological treatment of domestic sewage through duckweed-cum-fish culture: a pilot-scale study. Indian Journal of Fisheries, 57, 4, 4551.

[21] Gürtekin, E. ve Şekerdağ, N. (2008). Son çökeltme havuzlarında su mercimeğinin (Lemna minor L.) rolü. SAU. Science Journal, 12, 1, 28-31.

[22] Ozengin, N. ve Elmaci A. (2007). Performance of Duckweed (Lemna minor L.) on Different Types of Wastewater Treatment. Journal of Environmental Biology, 28, 2, 307-314.

[23] Sims, A., Gajaraj, S., ve Hu, Z.Q. (2013). Nutrient removal and greenhouse gas emissions in duckweed treatment ponds. Wat. Res., 47, 3, 1390-1398. 